\title{
Bibliography of manuscript sources
}

\section{BEINECKE LIBRARY, YALE UNIVERSITY}

Osborn MS bio3, b426 Religious commonplace books of the Cholmondeleys of Vale Royal

Osborn MS bi43 Classical commonplace book of Sir Thomas Aston

Osborn MS b203 Thomas Lytler's life of Lady Mary Cholmondeley

Osborn MS fb6o, fbi78 Separate collections belonging to Sir Richard Grosvenor

\section{BODLEIAN LIBRARY, OXFORD}

Ashmole MS 854 Miscellaneous political papers

Bankes MS I4/26, 38/29, 62/I, 62/34 Returns of gentleman who remained in London in the $1630 \mathrm{~s}$

Nalson MS, vol. I3 Miscellaneous political papers

\section{BRITISH LIBRARY, LONDON}

Additional MS II332, II333 Miscellaneous political papers

Additional MS 33935, 33936 Moreton correspondence

Additional MS 36913, 369I4, 36918 Aston correspondence

Additional MS 7000 Harley correspondence

Harleian MS 583 Legal case reports

Harleian MS I988, 2078, 2079, 2090, 2095, 2I73 Randle Holmes I and II's collections of papers relating to the history of Cheshire

Harleian MS 2017 Grosvenor papers, including the August $\mathrm{I}_{42} 2$ Cheshire Remonstrance

Harleian MS 2I25 Randle Holmes II's Chester Annals

Harleian MS 2129 Funeral certificates of Randle Holmes I and II

Harleian MS 2I35 Civil War papers relating to Cheshire I643-45 
Harleian MS 6424 Bishop Warner's diary of the House of Lords, I64I-42 Harleian MS 6607 Commonplace book of John Bruen

Sloane MS I467 Miscellaneous political papers

\section{CHESHIRE ARCHIVES AND LOCAL STUDIES, CHESTER}

DBW P/J/6, 7, 8 Thomas Wilbraham's household and farm accounts, I6I3-42

DCC I4 Letter book of Mayor Cowper of Chester, I64I-42

DCH/L Cholmondeley papers

DDX 210/I Wilbraham Family diary

DDX 384 Thomas Mainwaring's diary, I649-59

DDX 69/9 Henry Bradshawe's account book, I637-45

DLT BI Epic poem on the history of Cheshire by Richard Bostock

DLT B44 Antiquarian notes by Sir Thomas Aston and others

DNE 7 Needham of Shavington accounts

DSS I/I, 4 Shakerley of Hulme correspondence

EDA 3/I Register of Bishop Bridgeman

EDC I Chester consistory court case book

EDC 5 Chester consistory court case files

EDV I/33 Chester diocese correction book, I634

ML Chester Mayor's letters

P8/I3/2 Frodsham churchwardens' accounts

Pi8/3608 Tilston churchwardens' accounts

P39/8/I Marbury churchwardens' accounts

QJB I/5, I/6 Cheshire Quarter sessions order books, I6I9-40, I640-50

QJB 2/5 Cheshire petty sessions book

QJF Cheshire quarter sessions files

WS Cheshire Wills series

ZCR 63/2/6 Lieutenancy book of Thomas Leigh of Adlington, c.I625-42

ZCR 63/2/I9 Commonplace book of William Davenport of Bramhall

ZCR 63/2/34 Notes of Adlington display

ZCR 63/2/35 Cheshire church notes c.I633

ZCR 63/2/69I/I Grosvenor correspondence

ZCR 63/2/692/25 Petition in defence of the Chester Exchequer court, c.I650

ZCR 63/2/694/20, 23-5 Inventories of Crewe family paintings at Utkinton Hall

ZCR 63/2/695 Crewe family commonplace book

ZCR 63/2/696 Religious commonplace book of John Crewe

ZCR 72 Cotton family papers

\section{CHESTER PUBLIC LIBRARY}

MS 94/3 Edward Whitby's list of mayors, 1300-1620

\section{CHETHAM'S LIBRARY, MANCHESTER}

MS A.6.8 Separate collection and notes on the Adlington display Mun.E.8.22 Cheshire pedigree roll belonging to the Leighs of Adlington 


\section{DERBYSHIRE RECORD OFFICE, MATLOCK}

D258/34/69 Gell family papers

\section{EAST SUSSEX RECORD OFFICE, LEWES}

Glynde Place MS 556 Fitton family letters

\section{EATON HALL, CHESHIRE}

Grosvenor MS 24, 29 Papers relating to Cheshire local government Grosvenor MS, Misc. 6 Grosvenor family commonplace book

\section{FLINTSHIRE RECORD OFFICE, HAWARDEN}

CR 20I7/TP97 Letters of David Pennant, sheriff of Flintshire, $\mathrm{I}_{42}$

\section{HOUGHTON LIBRARY, HARVARD UNIVERSITY}

MS Eng I266, vols I and 2 Separate collections belonging to Sir Richard Grosvenor

\section{HUNTINGTON LIBRARY, SAN MARINO, CALIFORNIA}

Ellesmere MS, EL iII4 Cheshire armorial, late sixteenth century

Ellesmere MS, EL 7764 Manuscript copy of the Chester neutralist petition, July ${ }^{6} 642$

\section{JOHN RYLANDS LIBRARY, MANCHESTER}

EGRI/8/3/6, 3/3/3/2 Booth family papers in the Grey of Stamford collection English MS I09I Letter book of Thomas Cholmondeley, ship money sheriff, I637-38 Leigh of Lyme Correspondence of the Leigh family of Lyme Park Tatton of Wythenshawe Booth family letters MSS 25I-6

\section{LONGLEAT HOUSE, WILTSHIRE}

Whitelocke papers, vol. 2I Sir James Whitelocke's assize charges

\section{NORTHAMPTONSHIRE RECORD OFFICE, NORTHAMPTON}

Finch Hatton MS I33 William Dugdale's lists of commissioners of array

\section{PARLIAMENTARY ARCHIVES, LONDON}

$\mathrm{HL} / \mathrm{PO} / \mathrm{JO} / \mathrm{I} / 53$ Cheshire Petition in defence of episcopacy, February I64I $\mathrm{HL} / \mathrm{PO} / \mathrm{JO} / \mathrm{IO} / \mathrm{I} / 74$ Cheshire petition in defence of the prayer book, December I64I House of Lords main papers Letters, papers and petitions to the House of Lords 


\section{SENATE HOUSE LIBRARY, UNIVERSITY OF LONDON}

MS 285 Separate collection belonging to Sir Richard Grosvenor

\section{STAFFORDSHIRE RECORD OFFICE, STAFFORD}

Dı287/9/8, I8/2 Bishop John Bridgeman's papers and correspondence

\section{THE NATIONAL ARCHIVES, LONDON}

C 193/12/2 List of commissioners for the forced loan, I626-27

C I93/13/i Liber pacis, c.162I-22

C 219 Parliamentary election indentures

C 23I/5 Crown office docquet book

CHES 2I/3 Chester Great Sessions order book

CHES 24 Chester Great Sessions files

E IoI/547/5 Archbishop Laud's account book

E I63/18/12 Liber pacis, I626

$\mathrm{PC} 2$ Privy Council registers

PROB II Prerogative Court of Canterbury wills

SP I6 State Papers Domestic, Charles I

SP 28 Commonwealth Exchequer papers

STAC 8 Star Chamber cases of James I's reign

\section{TRINITY COLLEGE, DUBLIN}

MS 4I7 Latin notebook of Sir Richard Grosvenor

\section{UNIVERSITY COLLEGE OF NORTH WALES, BANGOR}

Mostyn MSS, 269I, 427I-2, 9082 Papers and correspondence of the Whitmore family 